\title{
Appropriate Technology for Golden Rice Farm of Thailand
}

\author{
Cha-aim Yindee \\ Regional Development Strategies Program \\ Surindra Rajabhat University \\ Email: chaaimyindee@gmail.com
}

\section{Doi:10.5901/mjss.2014.v5n1p587}

\begin{abstract}
The research was qualitative approaches. The research design for qualitative research was In-Dept Interview by using Ethnographic research technique with 20 Thai stakeholders composing of local wisdom peoples, community leaders and farmers who live at Chao Praya River in Phra Nakhon Si Ayutthaya Province, the Middle region of Thailand. The content from qualitative research was analyzed to construct the questionnaire for quantitative research. Factor analysis was used for determination the component factors. The objectives of this research were 1) to study methods and expertises of appropriate technology for golden rice farm from stakeholders composing of local wisdom peoples, community leaders and farmers, and 2) to analyze content of methods and expertises of appropriate technology for golden rice farm from stakeholders composing of local wisdom peoples, community leaders and farmers. The Interview results were used to construct items for factor analysis to identify the component of methods and expertises of appropriate technology for golden rice farm from stakeholders composing of local wisdom peoples, community leaders and farmers. There were 6 components were constructed from 50 items. The 6 components were Way of life in the past of farmers, Culture and belief of rice farming, Local wisdom of rice cultivation, Appropriate technology using in rice farming, Modern technology for living, and Modern technology for rice farming.
\end{abstract}

Keywords: Appropriate Technology / Golden Rice Farm / Thailand

\section{Introduction}

A drainage basin or watershed is an extent or an area of land where surface water from rain and melting snow or ice converges to a single point at a lower elevation, usually the exit of the basin, where the waters join another water body, such as a river, lake, reservoir, estuary, wetland, sea, or ocean. For example, a tributary stream of a stream which joins a small river, which is branch of a larger river, is thus part of a series of sequentially smaller area but higher elevation drainage basins (watersheds). The final destination is an estuary or an ocean and it sends all the water falling on the surrounding land into a central river and out to the sea. River basin is a low land locating a long with different rivers of the world such as Chao Phraya River, Mekong River, Euphrates River, and Tigris River. These rivers were historical importance as origin of world civilization. Currently, some of them are still important like as the past and it was selected to world heritage such as Chao Phraya River Basin in in Phra Nakhon Si Ayutthaya Province, the Middle region of Thailand (Putthawuttikai, 2006; Wikipedia, 2013; DeBarry, 2004). The Characteristics of river basin, the ground soil has high fertility because it is flood area, therefore the water flows with sediments of various nutrients and minerals to accumulate at river basin. It is flourish area of food for human, animal and plants. These factors stimulate people to live here with high density, therefore majority of Thai people who live at Cha Phraya River will be rice farmers because rice is main grain food of them (Rice Department, 2013).

In the past, agricultural occupation was done for living or response to family demand. Most of agriculture depends on nature, therefore the labor forces of family members and animal power of cow or buffalo for plough. Rice and other plants have been cultivated according to local wisdom with invented tools of appropriate technology such as plough handle, harrow, sickle and hoe. It needs little capital for rice cultivation because they use these simple tools and domestic animal for farming. The agriculturist who cultivates rice at river basin is called low flooded farmer. Moreover, the different species of rice were used as seeding (Rice Department, 2013).

Presently, the modern technology has been introduced for rice cultivation to produce this main grain food and production in terms of commercial purpose. The Ethnic group in the civilian of "Chao Phraya River Basin" is an important people of rice production of the world. Thailand is able to produce rice about 27 million tons and is the first exporter of rice of the world (Trimontree, 2007)

Golden rice refers to worth or value of production in terms of product transformation of rice to be numerous 
products whether desserts, food, and drugs. These make a lot of money for them. The characteristics of golden rice farming use the majority of land for rice farming, and the other parts use for different plants cultivation and animal husbandry according to appropriateness of land. From the past to present, the Kingdom of Thailand, the river basin in Middle region of country such as Cha Phraya River basin starting from Nakhon Sawan Province to Bangkok Metropolis. Phra Nakhon Si Ayutthaya Province has a largest area for low land rice farming because it is flooding area. Therefore, it is named as golden rice farming area since, particularly, at present; the modern technology is introduced for rice cultivation. This area is able to cultivate the rice for the whole year with at least twice times a year when comparing with the past that is was able to cultivate only once a year. Moreover, this area is capable to cultivate numerous plants and domesticate various kinds of animals for the whole year (Rice Department, 2013; Putthawuttikai, 2006).

In the social and cultural viewpoints, golden rice, vegetables, and fruits are able to cook as diverse food menus. This affects to the way of life, value and belief of golden rice, when it is considered on the growing process of rice by starting at rice with young paddy. It is called rice pregnancy, the farmer will invite "Mae Posop or Mother of Rice" to look after the rice stem to be strong and gain more rice grains. Consequently, harvesting time and carrying it to house, they will make a merit that called "Boon Lan" for rice. Marriage ceremony, the rice is roast to be "Khao Tok" with meaning of blessing for bride and groom to be rich and prosperous. Moreover, the rice is used as main food for numerous merit ceremonies. These activities aim to develop the mind of every people to be kind, mercy, and harmony and to unite including love each other among community people. It is accepted as smart idea of Thai ancestors of rice community (Rice Department, 2013).

Historical point of view, rice is main grain for consumption of a large number of people. This discovered from the evidence of Ban Chiang Civilization at Northeastern region of Thailand. According to archeological evidence, it was revealed that Mekong River basin at Northeastern region of Thailand, there was a community located in the pre-historical age about 4,000 years ago. The evidence indicated that the people cultivate the rice by spreading method a long with the flood plain area and letting it grow until the time of harvest is arrived. The farmer had transferred their knowledge and experience for long time ago (Natgsupa, 2006).

During $21^{\text {st }}$ Century, overall of food price of the world is extremely increased, it causes state of food insufficiency rapidly. Particularly, it is spreading over the developing and least developed countries. The development of new city in the globalization age has entered to low carbon society. In order to accomplish sustainable development, China as developing country also pay attention to the concept of low-carbon city, which integrates both elements of low-carbon economy and low-carbon society, provides a new model of sustainable urbanization for China toward ecological civilization and scientific development (Liu et al., 2009). The world population growth is rapidly increased, it causes the huge pollutions effecting to environmental quality and loss of biodiversity. The biodiversity loss has affected the balance of ecosystem. The fossil fuel energy consumption with extremely use, it cause the air pollution with increasing of sulfur dioxide, and then it turns to sulfuric acid that it is corrosive to various environment, even though it also effects to the golden rice farming as well (Thiengkamol, 2011e; Rice Department, 2013).

In the prior time, the production management of golden rice, the product purpose based on the natural conditional support was for household consumption mainly and production process was not complicated by using local wisdom and geographical technology but currently, the rice production is served for commercial demand and it need the different complicated modern technology to support. It uses different resources as an input resources and operation resources such as farm pushcart or tractor, harvester, and chemical fertilizer using for golden farming. This operation process needs to use fossil fuel (Boonlha, 2011; Chompukam, 2009). It needs the capital for rice production process, therefore, the rice farming uses the human power and animal power are disappear for more than two decades.

Moreover, it is also a process of destruction of minor group of farmer who are lack enough capital to sell their land or become a debtor of bank. Finally, they loss their own land and afterward, they become renter the field for rice cultivation. Even though the price of rice is increasing but the increased price is not good effect to agriculturist because the daily living cost is also increased as well, particularly the food price. Additionally, the chemical use of herbicide and insecticide also affected to their health. These chemical substances also accumulated in the fruits, vegetables and food unavoidably (Thiengkamol, 2009c; Chompukam, 2009).

Simultaneously, the market is belonging to middle man but the investment and risk is belonging to agriculturists. They do not have a chance to take part in decision making for market price. If they are able to use appropriate technology for operation of rice production and market price decision. The problem will be decreased (Chompukam, 2009; Thiengkamol, 2007). The appropriate technological management for golden rice farm of flooding land farmer referred to introduce the body of knowledge of process, method, and management of flooding land and step of occupation of agriculturist in flooding land at middle region of Kingdom of Thailand. There are different rivers flow through 
middle region of Thailand such as Chao Phraya River, Tha Jeen River, Pasak River, and Bang Pra Kong River. Chao Phraya is main river of Thailand that flows through Phra Nakhon Si Ayutthaya Province, particularly, Tambon Phraya Banlue, Amphoe Lat Bua Luang is the sub-district that Thai Muslim and Thai Buddhist are living together and this area has also faced with flooding every year. The leader is an essential person who will be able to lead to use appropriate technology, he needs to have proper knowledge and understanding to stimulate as changing agent in community because the community leader is the closed person with community people and he also understand the way of life and thought of community people including knowing the state of community problem and sharing happiness and suffer with community. He is a representative of people who cooperate with governmental sector; therefore, if he is able to introduce sufficiency economy concept and New Theory of agriculture together with his capability and role, he will be a leader of appropriate technology for golden rice farming (Thiengkamol, 2007; Kanjanakarun and Wongchaya, 2010). This is an opportunity to revitalize the golden rice farmer to be able to recover from debtor to be land owner again by using appropriate technological management of planning, organization management, personal management, and production process with body of knowledge of sufficiency economy and New Theory to manage soil, water, rice species selection, organic fertilizer use and water management with proper irrigation including controlling the variation of product price. Finally they will turn to be pro-actors (Thiengkamol, 2007, Thiengkamol, 2009c; Srichai, 2007).

From the mentioned above, it is noticeably seen that golden rice farming has implemented for long time ago but when the first national plan was established in 1961, the government of Thailand received fund from United State of America in terms of money and chemical substances of fertilizer and insecticide. Therefore, the new approach agriculture with monoculture dominantly. This causes the loss of biodiversity, particularly planting in garden fruits and the promotion of farm machine to use in farming. It is origin of deforestation for agricultural approach of monoculture. Moreover, the appropriate technology of local wisdom was disappeared in the same time. Afterward, in 1997 when the economic crisis occurrence, His Majesty the King of Thailand introduces sufficiency economy and New Theory as appropriate technology in terms of living and cultivating for sustainable development. Therefore, it is important to know and understand the component of factors that effected to appropriate technology for golden rice farming in Thailand at the Chao Phraya River basin in order to revitalize Thai golden farmer again by using Tambon Phraya Banlue, Amphoe Lat Bua Luang in Phra Nakhon Si Ayutthaya Province as studying area (Thiengkamol, 2007; Thiengkamol, 2009c; Chompukam, 2009; Thiengkamol, 2011e; Kanjanakarun and Wongchaya, 2010; Rice Department, 2013).

\section{Objectives}

The objectives of this research were as the followings:

1. To study methods and expertises of appropriate technology for golden rice farm from stakeholders composing of local wisdom peoples, community leaders and farmers.

2. To analyze content of methods and expertises of appropriate technology for golden rice farm from stakeholders composing of local wisdom peoples, community leaders and farmers.

\section{Methodology}

1. Qualitative research was used for data collection from In-Depth Interview form with 20 Thai stakeholders composing of local wisdom peoples, community leaders and farmers at Chao Phray River bank at Tambon Phraya Banlue, Amphoe Lat Bua Luang in Phra Nakhon Si Ayutthaya Province, in the Middle region of Thailand.

2. The research design for qualitative research was In-Dept Interview by using Ethnographic research technique with 20 Thai stakeholders composing of local wisdom peoples, community leaders and farmers (Chantarawanich, 1997; Thiengkamol, 2011a).

\section{Results}

\subsection{In-Depth Interview}

The results of In-Depth Interviews with 20 Thai stakeholders composing of local wisdom peoples, community leaders and farmers at Tambon Phraya Banlue, Amphoe Lat Bua Luang in Phra Nakhon Si Ayutthaya Province that located at Chao Phray River bank, in the Middle region of Thailand. It revealed that there were 6 components were constructed from 50 
items. The 6 components were Way of life in the past of farmers, Culture and belief of rice farming, Local wisdom of rice cultivation, Appropriate technology using in rice farming, Modern technology for living, and Modern technology for rice farming as illustrated in Table 1, 2, 3, 4, 5, and 6.

\subsubsection{Component 1: Way of life in the past of farmers}

The details of each item obtained from content analysis of In-Dept Interview were presented as the following in table 1.

Table 1: Content Analysis Results of Component 1

\begin{tabular}{|c|l|}
\hline Items & \multicolumn{1}{|c|}{ Component 1: Way of life in the past of farmers } \\
\hline 1 & $\begin{array}{l}\text { Golden rice filed of geographical technology transfers rice farming method to next generations by merit } \\
\text { culture of first farming and marriage. }\end{array}$ \\
\hline 2 & $\begin{array}{l}\text { Farmers at river basin of Thai and Khmer cultivate the farm plant and garden plant after the water level } \\
\text { reduced because soli sediment and nutrient substances will bring by the water. It needs no fertilizer. }\end{array}$ \\
\hline 3. & $\begin{array}{l}\text { Rice cultivation uses only cow and buffalo dung and bio-fertilizer, it will reduce expense for buying } \\
\text { chemical fertilizer. This is a factor of good quality of rice production. }\end{array}$ \\
\hline 4. & $\begin{array}{l}\text { Rice farming together of family members creates love, harmony and good relationship among parents, } \\
\text { children and relatives to produce the golden rice. }\end{array}$ \\
\hline 5. & $\begin{array}{l}\text { River basin farmers of both Thai and Khmer know sufficiency economy for farming and backyard garden } \\
\text { as food and selling for supplementary income. }\end{array}$ \\
\hline 6. & $\begin{array}{l}\text { River basin farmers have way of lives about rice cultivation and maintain the cow and buffalo as national } \\
\text { symbol. }\end{array}$ \\
\hline 7. & $\begin{array}{l}\text { Breadbasket means habitat in rice and water with flourishing of farming area in Thailand and Cambodia } \\
\text { that are the biggest areas of rice farming of countries. }\end{array}$ \\
\hline 8. & $\begin{array}{l}\text { Thai Muslim let Thai Buddhist to catch the rats from their farms and Thai Buddhist provides the dung to } \\
\text { Thai Muslim. }\end{array}$ \\
\hline 9. & $\begin{array}{l}\text { Golden rice farm is a way of life for both Thai Muslim and Thai Buddhist in the river basin and they are } \\
\text { the national backbone. }\end{array}$ \\
\hline
\end{tabular}

\subsubsection{Component 2: Culture and belief of rice farming}

The details of each item obtained from content analysis of In-Dept Interview were presented as the following in table 2.

Table 2: Content Analysis Results of Component 2

\begin{tabular}{|c|l|}
\hline Items & \multicolumn{1}{|c|}{ Component 2: Culture and belief of rice farming } \\
\hline 1 & $\begin{array}{l}\text { "Boon Koon Lan" is an important culture and it uses to cultivate the kindness to rice and mother of rice for } \\
\text { species selection and harmony in rice farming activity. }\end{array}$ \\
\hline 2 & $\begin{array}{l}\text { Harrow, plough, or spread rice culture is culture of use the space under a Thai house that is constructed from } \\
\text { natural material properly that does not destroy the environment quality. }\end{array}$ \\
\hline 3. & $\begin{array}{l}\text { "Khao Loy Nam" culture is ancient wisdom of river basin farmers of Thai and Khmer that transfer from } \\
\text { ancestors, therefore it should be conserved. }\end{array}$ \\
\hline 4. & $\begin{array}{l}\text { River basin farmers locate their houses at the river bank in order to be convenient to transport their product } \\
\text { and travel. }\end{array}$ \\
\hline 5. & $\begin{array}{l}\text { River basin farmers of both Thai and Khmer feed pig, duck, and chicken for ritual propose or as food or } \\
\text { fertilizer. }\end{array}$ \\
\hline 6. & $\begin{array}{l}\text { Ancient wisdom transfers belief of rice culture with Boon Prapanee Khao } 12 \text { months by using cow or buffalo } \\
\text { as media in ritual. }\end{array}$ \\
\hline 7. & $\begin{array}{l}\text { "Space under a Thai house culture" is accounted as ancient wisdom of river basin farmers, therefore the } \\
\text { house will be constructed with high space under a Thai house in order to avoid the flood and use in the dried } \\
\text { season. }\end{array}$ \\
\hline 8. & Farmer belief about "Boon Prapanee Khao 12 months" will good effect to maternal and child health. \\
\hline 9. & Thai and Khmer farmers are people who cultivate the rice in the river basin. \\
\hline 10. & $\begin{array}{l}\text { Boat race culture creates relationship and friendship between Thai Muslim and Thai Buddhist in Phra Nakhon } \\
\text { Si Ayutthaya Province. }\end{array}$ \\
\hline
\end{tabular}




\begin{tabular}{|c|l|}
\hline 11. & $\begin{array}{l}\text { Religion cultures of both Thai Muslim and Thai Buddhist are important; therefore it is holiday for praying } \\
\text { religion. }\end{array}$ \\
\hline 12. & $\begin{array}{l}\text { Thai Buddhists go to make merit at temple; they will prepare food for monk and neighbors with belief that } \\
\text { merit will support the golden farm. }\end{array}$ \\
\hline 13. & $\begin{array}{l}\text { Thai Muslim and Thai Buddhist have good relationship and depend on each other for rice cultivation culture, } \\
\text { even though they prays respect to different religions. }\end{array}$ \\
\hline 14. & $\begin{array}{l}\text { "Boon Prapanee Khao } 12 \text { months" or "Heet Sib Song" of river basin farmers of Thai and Khmer are similar. It } \\
\text { should be conserved. }\end{array}$ \\
\hline
\end{tabular}

\subsubsection{Component 3: Local wisdom of rice cultivation}

The details of each item obtained from content analysis of In-Dept Interview were presented as the following in table 3.

Table 3: Content Analysis Results of Component 3

\begin{tabular}{|c|l|}
\hline Items & \multicolumn{1}{|c|}{ Component 3: Local wisdom of rice cultivation } \\
\hline 1 & The big paddy ear will be selected and dried for keeping as seeding for golden rice farming. \\
\hline 2 & To farm, it should consider on the state of soil before others, this will lead to valuable and gain benefit. \\
\hline 3. & $\begin{array}{l}\text { Ancient wisdom of scarecrow to keep an eye on rice farm, at present it is still important, therefore it } \\
\text { should be conserved. }\end{array}$ \\
\hline 4. & $\begin{array}{l}\text { Farmer wisdom that uses the notice of colour and size of grain to check moisture is a local wisdom of } \\
\text { appropriate technology, therefore it should be conserved. }\end{array}$ \\
\hline 5. & $\begin{array}{l}\text { Wisdom of earthen dyke for irrigation will prevent the water to bring fertilizer from farm and be a walk } \\
\text { way to maintain the rice farm. }\end{array}$ \\
\hline 6. & Burn of ice stubble and mulch has wisdom rules of using the fire to kill insect, it should be conserved. \\
\hline 7. & $\begin{array}{l}\text { Farmer will use harrow to make ground to be smooth, therefore it is wisdom to make rice to get regular } \\
\text { fertilizer. }\end{array}$ \\
\hline 8. & $\begin{array}{l}\text { Soil preparation with soil turning, process of plough, and spreading plough of ancestors would get } \\
\text { plentifully rice and it becomes a golden rice farm. It is an appropriate technology. }\end{array}$ \\
\hline 9. & $\begin{array}{l}\text { Ancient wisdom of rice maintenance free from toxic and chemical substances, it should be reintroduced } \\
\text { again for health for all. }\end{array}$ \\
\hline 10. & Wisdom of product transformation of shrimp, snail and fish are important for rice farmers. \\
\hline
\end{tabular}

\subsubsection{Component 4: Appropriate technology using in rice farming}

The details of each item obtained from content analysis of In-Dept Interview were presented as the following in table 4.

Table 4: Content Analysis Results of Component 4

\begin{tabular}{|c|l|}
\hline Items & \multicolumn{1}{|c|}{ Component 4: Appropriate technology using in rice farming } \\
\hline 1. & Appropriate technology is used for golden rice farming to increase value and save the expense. \\
\hline 2. & $\begin{array}{l}\text { Ancient geographical technology is used for seeds selecting of paddy ear for worship and seeds for next year } \\
\text { cultivation. }\end{array}$ \\
\hline 3. & $\begin{array}{l}\text { Original rice farming by using cow and buffalo is decreasing the expense and increasing income, moreovere, there } \\
\text { are shrimp, snail, and fish that devastate the insects. It is an appropriate technology for golden rice farming. }\end{array}$ \\
\hline 4. & $\begin{array}{l}\text { Organic fertilizer used is an appropriate technology for soil and water conservation and it creates valuable for } \\
\text { ecosystem of water in rice farm to produce high quality of rice. }\end{array}$ \\
\hline 5. & Local technological use for golden rice cultivation is congruent to idiom of "In water has fish, In the field has rice". \\
\hline 6. & $\begin{array}{l}\text { Technological management, cow and buffalo dung are used instead of chemical fertilizer, the golden rice will grow } \\
\text { rapidly with less weeds and free from chemical substances. }\end{array}$ \\
\hline 7. & $\begin{array}{l}\text { Appropriate technology for rice movement by water vehicle of river basin farmer has high effectiveness and } \\
\text { expense saving. }\end{array}$ \\
\hline 8. & $\begin{array}{l}\text { To make "Khwun Khao" and to request blessing from "mother of rice" and to put bio-fertilizer while the rice has } \\
\text { young paddy, is an appropriate technology. }\end{array}$ \\
\hline 9. & Technological wisdom of water management is used to get better rice quality. It should be developed continuously. \\
\hline
\end{tabular}




\subsubsection{Component 5: Modern technology for living}

The details of each item obtained from content analysis of In-Dept Interview were presented as the following in table 5.

Table 5: Content Analysis Results of Component 5

\begin{tabular}{|c|l|}
\hline Items & \multicolumn{1}{|c|}{ Component 5: Modern technology for living } \\
\hline 1 & $\begin{array}{l}\text { Currently, farmer has no barn for rice storing but he/she sends the paddy to rice mill suddenly, therefore, } \\
\text { technological management should has mobile mill to get rice bran, paddy husk, polished rice, broken-milled } \\
\text { rice and germ rice for instance. }\end{array}$ \\
\hline 2 & $\begin{array}{l}\text { Technological management of surpassed rice with diverse product transformation are the value added of rice } \\
\text { to be dessert, food and drugs }\end{array}$ \\
\hline 3. & New Theory is an appropriate technology for river basin farmer for sufficiency economy. \\
\hline 4. & Assistant process for river basin farmer, should let farmer to participate as committee with proper number. \\
\hline
\end{tabular}

\subsubsection{Component 6: Modern technology for rice farming}

The details of each item obtained from content analysis of In-Dept Interview were presented as the following in table 6.

Table 6: Content Analysis Results of Component 6

\begin{tabular}{|c|l|}
\hline Items & \multicolumn{1}{|c|}{ Component 6: Modern technology for rice farming } \\
\hline 1 & $\begin{array}{l}\text { A large amount of chemical use in agriculture, it causes the toxic penetration in soil and water, moreover it } \\
\text { also affects to human and animal health. }\end{array}$ \\
\hline 2 & Technological management of water store and water drain are important for value added of golden rice farm. \\
\hline 3. & Learning on soil to be soil doctor according to His Majesty the King is useful for agriculturist. \\
\hline 4. & $\begin{array}{l}\text { Weather state and wrong season of water affect to the golden rice quality, it becaomes Laeu rice, Tod Yod } \\
\text { rice, Khaow Puang or Dok Lam Duan rice. }\end{array}$ \\
\hline
\end{tabular}

\section{Discussion}

It might be concluded that above study reflected to past and present of method and expertise for appropriate technological using in golden rice farming at Cha Phraya river basin of Middle region of Thailand. In order to conserve the golden rice species and conserve wisdom, culture and environment, it requires collaboration among all stakeholders whether local wisdom people, community leaders, farmers and governmental sectors to conserve golden rice to achieve ecosystem conservation based on appropriate technology with clean and green technologies and free from toxic and chemical substances. Furthermore, the stakeholders in community at Cha Phraya River Basin should recognize to the important of golden rice because it is national symbol of natural rice with good quality and good taste. Therefore, if the stakeholders take responsibility to drive for golden rice farming as national policy by emphasizing on value added through product transformation as dessert, food and drug. These will assist to conserve the golden rice to sustain for Thai people and global people to have a clean and green food for consumption. However, the new generation should pay attention to conserve local wisdom, culture and appropriate technology to support their quality of life with clean and green golden rice products in diverse product transformation. In addition, if the stakeholders involved in golden rice farming realizes the important of appropriate technological use to convert to be different products, it will essential driving force of national income. Therefore, Thai people will be a leader of rice exporting forever.

\section{Reference}

Chantarawanich, S. (1997). Qualitative Research. Bangkok: Chulalongkorn University Press.

Chompukam, P. (2009). Organization and Management. Bangkok:

DeBarry, P.A. (2004). Watersheds: Processes, Assessment and Management. John Wiley \& Sons.

Kanjanakarun, J. and Wongchaya, W. (2010). Adoption of Agricultural Innovation and Technology in Yonglae Village Community. MUTP research Journal, Vol. 4 No. 1 March 2010, pp. 92-101.

Liu Z, Dai, Y., Dong, C, and Qi, Y. (2009). Low-Carbon City: Concepts, International Practice and Implications for China. Retrieved from: http://en.cnki.com.cn/Article_en/cjfdtotal-csfy200906003.htm 
Natgsupa, C. (2006). Universal Sky Viewpoint- City Spirit Thai Ahom Scripture. Bangkok: Witheethat Institute.

Putthawuttikai, V. ( 2006). Geography of Thailand. Bangkok: Odian Store Publishing.

Rice Department. (2013). Rice as origin of Thai Culture. Bangkok: Rice Department, Ministry of Agriculture and Cooperatives.

Srichai, D. (2007). The Study of Sufficiency Economy Philosophy Application in Daily Lives of Pre-Cadet Students. Department: Curriculum, Instruction and Educational Technology, Field of study: Teaching Social Studies. Master of Social Science, Chulalongkorn University.

Thiengkamol, N. (2007). Globalization Administration. Bangkok: Saengchai Publishing.

Thiengkamol, N. (2009c). Environment and Development Book 2 (Food Security). Bangkok: Chulalongkorn University Press.

Thiengkamol, N. (2011a). Holistically Integrative Research. 2nd Edition. Bangkok: Chulalongkorn University Press.

Thiengkamol, N. (2011e). Environment and Development Book 1. (4th ed.). Bangkok: Chulalongkorn University Press.

Trimontree, B. (2007). Sunlight is Renewable Energy for Today. Bangkok: Scientific Fund of Dr. Preecha-Prapai Amatayakul Project Management.

Wikipedia. (2013). Tigris. Retrieved from: http://en.wikipedia.org/wiki/Tigris 
